\title{
QUEEN'S
UNIVERSITY
BELFAST
}

\section{PROS: The Programme for the Reform of the Law on Soliciting, 1976-1982}

Connell, K. (2020). PROS: The Programme for the Reform of the Law on Soliciting, 1976-1982. Twentieth Century British History, 31(3). https://doi.org/10.1093/tcbh/hwz032

Published in:

Twentieth Century British History

Document Version:

Peer reviewed version

Queen's University Belfast - Research Portal:

Link to publication record in Queen's University Belfast Research Portal

Publisher rights

The Author(s) 2019. Published by Oxford University Press. All rights reserved. This work is made available online in accordance with the publisher's policies. Please refer to any applicable terms of use of the publisher.

\section{General rights}

Copyright for the publications made accessible via the Queen's University Belfast Research Portal is retained by the author(s) and / or other copyright owners and it is a condition of accessing these publications that users recognise and abide by the legal requirements associated with these rights.

Take down policy

The Research Portal is Queen's institutional repository that provides access to Queen's research output. Every effort has been made to ensure that content in the Research Portal does not infringe any person's rights, or applicable UK laws. If you discover content in the Research Portal that you believe breaches copyright or violates any law, please contact openaccess@qub.ac.uk. 


\title{
$\underline{\text { Kieran Connell, Queen’s University Belfast }}$
}

\section{K.connell@qub.ac.uk}

\begin{abstract}
In the late-1970s a campaign was mounted to reform the legal landscape faced by sex workers, which had remained unaltered since a series of recommendations made in the Wolfenden Report were implemented by the government two decades earlier. While Wolfenden is commonly associated with the arrival of Britain's 'permissive' 1960s, when it came to the issue of prostitution it helped usher in even more restrictive conditions for sex workers. This article looks at attempts to challenge this status quo by focusing on the Programme for the Reform of the Law on Soliciting (PROS), which was founded in Birmingham in 1976 and became one of the most visible groups advocating for a change in the law. Its activities culminated with the 1982 Criminal Justice Act, which ostensibly abandoned the policy of imprisoning prostitutes on soliciting offences. The case of PROS, I argue, offers a further reminder of the afterlife of the liberalising ethos associated with the 1960s. Moreover, it provides a different way of engaging with a historical conjuncture more commonly associated with themes such as rising individualism, the fragmentation of leftwing activism and the arrival of Thatcherism.
\end{abstract}

\section{Keywords}

Prostitution, sex work, permissiveness, activism, identity politics 


\section{Introduction}

In the opening scene of Prostitute, Tony Garnett's 1980 feature film about the sex industry in Britain, three women are standing on a street in Balsall Heath - the major red light district of Birmingham - complaining about the slow pace of work. 'I haven't even got any bloody money yet', remarks one of the women, Rose, before giving up for the day and setting off to pick her children up from school. ${ }^{1}$ Prostitute was Garnett's directorial debut, though he had earlier made his name as a producer on Ken Loach’s classic Cathy Come Home (1966), which contributed to a national outcry over the extent of poverty and homelessness in postwar Britain. ${ }^{2}$ Garnett hoped Prostitute would lead to a similar debate about the status of sex workers. In keeping with his work with Loach, Garnett's approach was social realist: he spent four years researching his subject in Balsall Heath and minimized the use of professional actors, preferring instead to utilise the ordinary inhabitants of the world he was seeking to depict. This included a number of active prostitutes, including the woman who played the character of Rose. In the film, as Rose is making her way to collect her children, she is suddenly bundled into a police car by two detectives. Rose is brought to court, identified as a 'common prostitute', charged with soliciting and is eventually given a three month prison sentence due to her persistent offending. The opening act of Prostitute ends with Rose about to be led away, urging her probation worker to ensure that her children are not taken into care.

A central component of the film's narrative is the formation of a campaign group to advocate for women like Rose. Here, Garnett took inspiration from the Programme for the Reform of the Law on Soliciting (PROS), which was established in Birmingham in 1976 and

\footnotetext{
${ }^{1}$ Quoted in Tony Garnett, Prostitute (Kestrel Films, 1980).

${ }^{2}$ Nicholas Crowson, 'Revisiting the 1977 Housing (Homeless Persons) Act: Westminster, Whitehall, and the homelessness lobby’, Twentieth Century British History, 24 (2013), 424-447. See also Tony Garnett, The Day the Music Died: a memoir (London, 2016), 145-150.
} 
provided one of Garnett's entry-points into the Balsall Heath scene. ${ }^{3}$ Prostitute depicts the group's inaugural meeting, which is focussed on finding ways of ensuring that sex workers are aware of their legal position and rights. 'The law regards [prostitutes] as a public nuisance', a solicitor at the meeting explains. 'The law says you can be a prostitute...that's not a crime. What is a crime is if you go out on the street and tap [a man] on the shoulder and say, "how about it?”, Later, Jean - a character also played by a working prostitute - declares that it is the vice squad that are the real nuisance. 'If girls want to earn a bit of money', she remarks, 'let them earn a bit of money. Now you get sent to prison for nothing'. Finally, the focus turns to the possibility of a campaign that could seek to bring about a change in the law. To the mind of one participant, what was required was a combined approach: 'getting to our MP...influencing public opinion....and getting women on [our] side'. ${ }^{4}$

This article explores the real-life campaign by PROS to bring about changes in the laws around sex work from the mid-1970s to the early-1980s. Although PROS was a marginal organisation made up of a small core of dedicated activists, it became one of the most vocal advocates of sex worker rights in the country, and one that could call on a growing band of supporters both inside and outside parliament. On its own terms, therefore, PROS represents a compelling case study into the nature, practice and process of political activism in contemporary Britain, particularly given its focus on the relatively under-explored issue of prostitution. It presents a way of thinking about the 'spaces of advocacy' that were available to an organisation as it attempted to campaign for the rights of what remained one

\footnotetext{
${ }^{3}$ See Tony Garnett, 'My directorial debut: Prostitute', from internet source: http://www.bfi.org.uk/newsopinion/news-bfi/features/my-directorial-debut-prostitute (accessed 2 July 2018). See also Malcolm Fowler, comments on Prostitute script, c. 1978, Modern Records Centre, Warwick University, PROS papers, [henceforth PROS papers], 1100/3/2.

${ }^{4}$ Quoted in Garnett, Prostitute.
} 
of the most ostracised groups in society. ${ }^{5}$ And it allows us to shift our attention away from the London-based activism that continues to preoccupy historians. Although PROS did have a presence in the capital and was a regular visitor to Westminster, following its establishment in Birmingham the spaces in which its advocacy developed most strongly were in provincial towns and cities such as Leamington Spa in Warwickshire, Sheffield in South Yorkshire and Bristol in South West England. PROS therefore provides a way of thinking about the regional dimension of non-governmental activism - the challenges that came as a result of being away from the country's administrative and media hub, and the imaginative tactics that that were required in order to expand the organisation's spheres of influence. ${ }^{6}$

The story of PROS also allows for a re-engagement with broader historical themes. First, the success that PROS found in attempting to bring the issue of sex worker rights to public attention demonstrates the enduring reach of a liberalising ethos more commonly associated with the 1960s. ${ }^{7}$ The campaign fought by PROS offers a further example of the afterlife of the 'permissive society' of that decade, and the landmark social reforms that were introduced most famously with the 1967 Sexual Offences Act, which ushered in the partial decriminalisation of homosexuality in England and Wales. PROS is a reminder of the limitations of that notionally permissive moment, particularly when it came to the wellbeing of those women working in a sexual economy that had - with the proliferation of strip clubs, a succession of high profile 'call girl' scandals, and the use of increasingly explicit imagery

\footnotetext{
${ }^{5}$ Stephen Brooke, 'The sphere of sexual politics: the Abortion Law Reform Association, 1930s to 1960s', in Nick Crowson, Matthew Hilton and James McKay (eds), NGOs in Contemporary Britain: Non-State Actors in Society and Politics Since 1945 (Basingstoke, 2009), 83.

${ }^{6}$ See Helen Smith, 'Working-class ideas and experiences of sexuality in twentieth-century Britain: regionalism as a category of analysis', Twentieth Century British History, 29 (2018), 58-78.

${ }^{7}$ Matthew Hilton, Chris Moores and Florence Sutcliffe-Braithwaite, 'New Times revisited: Britain in the 1980s', Contemporary British History, 31 (2017), 9; Daisy Payling, “'Socialist republic of south Yorkshire”: grassroots activism and left-wing solidarity in 1980s Sheffield', Twentieth Century British History, 25 (2014), 602-627.
} 
in the print media and elsewhere - erupted into public consciousness in the post-war years. ${ }^{8}$ And it also demonstrates the extent to which - running counter to popular accounts of the period by writers such as Dominic Sandbrook - the 1960s functioned as a stimulus rather than an endpoint, both with respect to the passing of further legislation and in terms of the energy and organisational structures of subsequent movements as they continued to proliferate in the 1970 s and beyond. ${ }^{9}$

The case of PROS also hints at a different way of engaging with a conjuncture more commonly associated with the landslide victory of Margaret Thatcher's Conservative Party in May 1979. The achievement of Thatcherism, it is often argued, was the extent to which it tapped into what had already become an increasingly individualised climate wherein collective affiliations were gradually being supplanted by an aspirational politics limited to the individual. Within this narrative, the identity politics of gender, race and sexuality that emerged on the left from the late-1960s onwards are positioned as having inadvertently contributed both to the predominance of a 'popular individualism' and to the damaging fragmentation of left-wing activism - something commonly associated with the final, highly factional Women's Liberation conference in Birmingham in 1978. ${ }^{10}$ As such divisions continued into the 1980s, underpinned by heated debates about the relative primacy of

\footnotetext{
${ }^{8}$ Frank Mort, 'Striptease: the erotic female body and live sexual entertainment in mid-twentieth-century London’, Social History, 32 (2007), 27-53; Frank Mort, Capital Affairs: London and the Making of the Permissive Society (New Haven and London, 2010); Marcus Collins, 'The pornography of permissiveness: men's sexuality and women’s emancipation in mid-twentieth-century Britain', History Workshop Journal, 47 (1999), 99-120; Rebecca Loncraine, 'Bosom of the nation: Page Three in the 1970s and 1980s', in Mina Gorji (ed.), Rude Britannia (Abingdon, 2007), 96-111.

${ }^{9}$ Stuart Hall, 'The great moving right show', Marxism Today (January 1979), 16; James McKay and Matthew Hilton, Introduction to Crowson, Hilton and McKay (eds), NGOs in Contemporary Britain, 13-15; Frank Mort, 'Victorian afterlives: sexuality and identity in the 1960s and 1970s', History Workshop Journal, 82 (2016), 199212. See also Dominic Sandbrook, White Heat: A History of Britain in the Swinging Sixties (London, 2006). ${ }^{10}$ Jeska Rees, ‘A look back in anger: the Women’s Liberation Movement in 1978', Women’s History Review, 19 (2010), 346.
} 
gender, race, class and sexuality, so the politics of Thatcherism expanded into a project that was shaped not only by a populist emphasis on issues such as law and order but increasingly also by an avowed reaction against the legacies of permissiveness - both through a rhetorical commitment to a return to 'Victorian virtues' and, by the late-1980s, through the introduction of legislation that imposed significant limits on the tolerance of homosexuality in particular. ${ }^{11}$ While historians continue to identify this as a period of indelible fragmentation, what is striking about PROS is the extent to which, in spite of its marginality, the group was able to marshal a diverse range of constituents in support of its campaign - from other sex worker advocacy groups, feminist organisations and civil rights groups to MPs from across the political spectrum and, perhaps most importantly, prostitutes themselves. In the polarised context of late-twentieth century Britain, the example of PROS calls attention to the parallel importance of small-scale processes of 'mediation', what Raymond Williams defined as ‘acts of intercession, reconciliation' or 'interaction' between different and often-competing constituencies. $^{12}$ The focus PROS kept to the specific issue of solicitation undoubtedly helped here, even if - as Judith Walkowitz has shown - prostitution had re-emerged in the late-1970s as a highly controversial issue, not least in feminist circles. ${ }^{13}$ Yet PROS brought Women's Liberation groups into their organisation and took inspiration from their core

\footnotetext{
${ }^{11}$ On identity politics and fragmentation, see Lisa Power, No Bath But Plenty of Bubbles: An Oral History of the Gay Liberation Front, 1970-1973 (London, 1995), 61; Hazel Carby, 'White women listen! Black feminism and the boundaries of sisterhood', in Centre for Contemporary Cultural Studies (eds), The Empire Strikes Back: Race and Racism in Contemporary Britain (London, 1982), 212-215; Kieran Connell, Black Handsworth: race in 1980s Britain (Berkeley, 2019), 18-52. On the role of Victorian values in the politics of Thatcherism, see Raphael Samuel, 'Mrs Thatcher's return to Victorian values', Proceedings of the British Academy, 78 (1992), 929; Florence Sutcliffe-Braithwaite, 'Neoliberalism and morality in the making of Thatcherite social policy', The Historical Journal, 55 (2012), 497-520; Matt Cook, 'AIDS, Mass Observation, and the fate of the permissive Turn', Journal in the History of Sexuality, 26 (2017), 239-272.

${ }^{12}$ Raymond Williams, Marxism and Literature (Oxford, 1977), 98.

${ }^{13}$ Judith Walkowitz, 'Feminism and the politics of prostitution in King's Cross in the 1980s', Twentieth Century British History, 30 (2019), 231-263.
} 
campaign methods, especially the emphasis on the political power of personal testimony. In PROS, this often meant that women like Rose - active sex workers who had historically been a key focus for anxieties about the extended reach of Britain's sexual underworlds - took on important advocatory roles. ${ }^{14}$ The focus on the practicalities of the sex industry, from the point of view of the women who worked within it, helped to shape an emergent political consensus around the need for reform. In October 1982, this came to a head with the passing of a Criminal Justice Act, which formally abandoned the policy of imprisoning prostitutes on soliciting offences. The Act was in a host of ways problematic. But it did represent the first amendment to the legal landscape faced by prostitutes since the late-1950s, and helps further problematize the lip-service increasingly paid to 'Victorian virtues' in Thatcher's Britain. ${ }^{15}$ The story of the campaign behind this change in the law shows how some groups, however peripheral they were to broader currents, maintained an ability to plot mediatory routes through a shifting political conjuncture.

\section{Context and establishment}

The legal framework around prostitution in England and Wales was established in the first half of the nineteenth century. ${ }^{16}$ Key was the 1824 Vagrancy Act, which determined that a 'common prostitute' in a public street or highway was liable to prosecution, fines and potentially imprisonment on charges of being 'idle and disorderly'. It was a circular piece of legislation - no legal definition for 'common prostitute' was provided, yet being convicted as

\footnotetext{
${ }^{14}$ Cate Haste, Rules of Desire: Sex in Britain, World War 1 to the Present (London, 2002), 187-192; Mort, Capital Affairs, 281-327.

${ }^{15}$ There are parallels here with the funding allocated to local authorities to deal with AIDS in the 1980s. See Virginia Berridge, AIDS in the UK: the Making of a Policy, 1981-1994 (Oxford, 1996). For a good overview of the broader contradictions of the Thatcher project, see Robert Saunders, 'The Many Lives of Margaret Thatcher, English Historical Review, 132 (2017), 638-658.

${ }^{16}$ A different legal situation was in play in Scotland. See Louise Settle, Sex for Sale in Scotland: Prostitution in Edinburgh and Glasgow, 1900-1939 (Edinburgh, 2016).
} 
such was enough for the chances of subsequent convictions to rise significantly. ${ }^{17}$ The later nineteenth century witnessed the passing of a succession of oppressive laws as a result of concerns about public morality and venereal disease. ${ }^{18}$ Although some of this legislation was challenged and ultimately overturned as a result of a campaign led by the feminist reformer Josephine Butler, the legal narrative that defined prostitutes as 'disorderly', a 'nuisance' and a potential threat to the moral and social fabric had become entrenched. Indeed, it was an ethos that persisted well into the twentieth century.

Here, the most significant impetus for legislative change came from the Departmental Committee on Homosexual Offences and Prostitution, which was chaired by the educationalist Sir John Wolfenden and published its findings in 1957. To some degree, the Committee's position with respect to prostitution was consistent with its rationale for arguing for the partial decriminalisation of homosexuality: sex between consenting adults was seen as an essentially a private matter, something that, so long as it took place behind closed doors, was 'not the law's business' ${ }^{19}$ The problem with Wolfenden's 'ethic of privatized morality' was that when it was applied to the issue of prostitution as it actually operated in Britain, an active application of the law was required in order to render this kind of sex private. ${ }^{20}$ While the Committee's liberalising tendency was evident with its suggestion that women convicted of prostitution offences should be offered the chance to undertake a programme of reform in lieu of a custodial sentence, this was far outweighed by its other recommendations. It argued that the term 'common prostitute' should remain in place, and that penalties should be raised

\footnotetext{
${ }^{17}$ Susan Edwards, Women on Trial: a study of the female suspect, defendant and offender in the criminal justice system (Manchester, 1984), 55; Helen Self, Prostitution, Women and the Misuse of the Law: the fallen daughters of Eve (London, 2003), 38.

${ }^{18}$ See Judith R. Walkowitz, Prostitution and Victorian society: women, class and the state (Cambridge, 1980).

${ }^{19}$ Lord Wolfenden, quoted in Frank Mort, 'The Ben Pimlott memorial lecture 2010: The permissive society revisited', Twentieth Century British History, 22 (2011), 273.

${ }^{20}$ Mort, 'The permissive society revisited', 273.
} 
for convictions with the prospect of prison sentences for repeat offenders. With the ultimate ambition of driving prostitution off the streets, Wolfenden also proposed that police should no longer be formally required to prove that a prostitute was soliciting to the 'annoyance' of the general public in order for there to be a successful prosecution. ${ }^{21}$

Unsurprisingly, these recommendations were quickly implemented. The direction of travel had been indicated when Harold Macmillan's Conservative government passed, without waiting for the formal publication of the Committee's findings, the 1956 Sexual Offences Act, which made it an offence for two or more prostitutes to operate out of the same premises and made partners, husbands and other cohabitees of a sex worker's home liable to prosecution for living on 'immoral earnings'. The Committee's own attitude to prostitution was alluded to by the fact that, despite hearing evidence from a vast range of expert witnesses, this did not include a single practising sex worker. ${ }^{22}$ In July 1959 the government introduced its Street Offences Act. This formally made street soliciting a crime, and granted the police powers of arrest without the need for them to prove public annoyance. The maximum fine for solicitation was increased from forty shillings to $£ 25$, while the maximum prison sentence - invoked at the third or subsequent offence - was raised from fourteen days to three months. ${ }^{23}$ The legal category of 'common prostitute', which was introduced in 1824 and continued to mean that women with prior convictions were introduced as such in court and subsequently liable to be arrested again simply by virtue of being present on the streets, remained. ${ }^{24}$ By the late-1970s, prostitutes could face fines of up to $£ 200$ as well as a three

\footnotetext{
${ }^{21}$ Julia Laite, Common Prostitutes and Ordinary Citizens: commercial sex in London, 1885-1960 (Houndmills, 2012), 196.

22 Laite, Common Prostitutes, 195; Mort, 'The permissive society revisited', 274.

${ }^{23}$ Eileen McLeod, Women Working: prostitution now (London, 1982), 92; Laite, Common Prostitutes, 196-9.

${ }^{24}$ Susan Edwards, 'The legal regulation of prostitution: a human rights issue', in Graham Scrambler and Annette Scrambler (eds), Rethinking Prostitution: purchasing sex in the 1990s (London, 1997), 61.
} 
month jail term, and the number of women convicted annually on prostitution offences in England and Wales had in a little over a decade more than doubled to $3,839 .{ }^{25}$

If this situation gave PROS its founding impetus, the immediate organisational blueprint came with the emergence of a succession of prominent campaigns for sex worker rights outside of Britain. In the United States, for example, the former sex worker Margo St James founded Cast Off Your Old Tired Ethics (COYOTE) in 1973, which staged publicitygenerating events such as 'hookers' balls' and 'loiter-ins' with the ultimate aim of reconceptualising prostitution as a credible profession which therefore required adequate legal protection for those who worked within it. ${ }^{26}$ Then, following the murder of two prostitutes in France, in June 1975 some sixty prostitutes occupied a church in Lyons to demand greater protection and an end to what was regarded as the repressive approach of the French police. During the protest, which quickly spread to other cities, sex workers threatened to withdraw their labour without an immediate change in the established practice of issuing prostitutes with heavy fines. ${ }^{27}$ The protest was widely covered by the British media, and resulted in the formation of campaign groups that aimed to address the specific situation faced by sex workers in Britain. In November 1975, Helen Buckingham, a Londonbased sex worker who would become increasingly visible as a spokesperson for the off-street call girl trade, co-founded Prostitutes United for Social and Sexual Independence (PUSSI). She later worked closely with Selma James, the American writer, activist and key player in

\footnotetext{
${ }^{25}$ PROS Bulletin no. 3 (1979), 6, PROS papers, 1100/2/1; Joan Vickers, 'Prostitution in the context of the Street Offence Act', in D.J. West (ed), Sex Offenders in the Criminal Justice System (Cambridge, 1980), 118.

${ }^{26}$ Michael Binyon, 'Working girls of the demi-monde unite in Washington', The Times, 25 June 1976, 6. See also Valerie Jenness, 'From sex as sin to sex as work: COYOTE and the reorganization of prostitution as a social problem', Social Problems, 37 (1990), 403 and Margo St. James, 'What's a girl like you...?', in Claude Jaget (ed.), Prostitutes: our life (Bristol, 1980), 189-202.

${ }^{27}$ Anon., 'Marseilles and Nice prostitutes join protest', The Times, 7 June 1975, 4. See also Claude Jaget, 'Hookers in the house of the lord', in Jaget (ed.), Prostitutes, 33-54.
} 
the establishment that same year of the English Collective of Prostitutes (ECP). ${ }^{28}$ Ideologically, the ECP was shaped by a Marxist-feminist analysis that deemed all work undertaken by women to be forms of prostitution, a position that was fused with a highprofile approach to campaigning, with the staging of set-pieces designed to capture the attention of the media. In 1979, for instance, Buckingham tapped into renewed popular interest in the high society clientele of sex workers by threatening to name the sitting MPs who had used the services of prostitutes. ${ }^{29}$ Three years later, inspired by the earlier protests in France, ECP activists staged a twelve-day sit-in at the Holy Cross church in King's Cross, a major red light area of London. Their demands were 'the total abolition of all laws concerning prostitution' and 'immediate protection, welfare [and] housing for women who want to get off the game'. 30

PROS was established in November 1976. The key players included Eileen McLeod, an academic at Warwick University who had previously been employed as a probation officer; Louise Webb, who had studied under McLeod at Warwick and had a background in community work; Malcolm Fowler, a solicitor advocate who often dealt with prostitution cases in Birmingham; and a number of sex workers including Kim L and Nancy S, both of whom appeared as actors in Tony Garnett's Prostitute. ${ }^{31}$ This breadth of expertise, and firsthand familiarity with the consequences of the existing laws around prostitution, perhaps contributed to the group's more focussed, reform-orientated platform - certainly when

\footnotetext{
${ }^{28}$ McLeod, Women Working, 119; Ana Lopez \& Jenn Clamen, 'Why we need a sex workers' union', in Sophie Day \& Helen Wood (eds), Sex Work, Mobility and Health in Europe (London, 2004), 42.

${ }^{29}$ This broader interest was stimulated by the high-profile case of Cynthia Payne, a London brothel-keeper whose premises was raided in 1978 and was alleged to have several high-profile clients. Payne was convicted of running a disorderly house in 1980. See Paul Bailey, An English Madam: Life and Work of Cynthia Payne (London, 1982).

${ }^{30}$ English Collective of Prostitutes, 'Campaigning for legal change', in Scrambler \& Scrambler (eds), Rethinking Prostitution, 88; English Collective of Prostitutes, quoted in McLeod, Women Working, 120.

${ }^{31}$ In line with the requests of oral history interviewees, I am using these pseudonyms to protect their identity.
} 
compared to the ECP, an organisation which, according to observers, actually had relatively few active prostitute members. ${ }^{32}$ PROS advocated the abolition of prison sentences for soliciting, and an end to the legal use of 'common prostitute'. The former was deemed a highly disproportionate punishment for what the group argued was an essentially 'victimless “crime”, while the latter was seen to be simultaneously 'insulting', prejudicial and the major obstacle to a woman's right to a fair trial. The group further advocated the reversal of one of the key interventions of the 1959 Street Offences Act, which designated that police officers were not obliged to prove that a prostitute was creating a public nuisance. Instead, it suggested the burden of evidence be shifted onto 'people experiencing nuisance in the street'. Where this was proven, it was advocated that a system of graduated fines or other noncustodial measures should be introduced. ${ }^{33}$

According to McLeod, who detailed her experiences in PROS in her 1982 study Women Working: Prostitution Now, the group made the conscious decision to focus on campaigning around a series of relatively modest goals rather than also attempt the servicebased, 'welfare' approach that many other voluntary organisations were in the 1970s coming under pressure to fulfil. By 1981 PROS was in receipt of £5,000 per annum from the Barrow-Cadbury Trust, with the majority of this figure used to cover the cost of hiring Louise Webb as the group's full-time organiser. Barrow-Cadbury had a reputation for funding marginal organisations, and PROS recognised that the prospect of raising funds from elsewhere would largely depend on developing a much wider programme of practical services. The concern in PROS was that when it came to the issue of prostitution, this would be based on 'some idea of deterring [sex workers] or rescuing them', and the development of

\footnotetext{
${ }^{32}$ According to one report, the ECP was made up of 'professional agitators' funded by the Greater London Council. See report in the London Evening Standard, 23 November 1982, Women's Library, London School of Economics, ECP Papers, 3AMS/B/16/05. See also David Bouchier, The Feminist Challenge: the Movement for Women's Liberation in Britain and the USA (London, 1983), 144.

${ }^{33}$ PROS Bulletin, no. 1 (April 1977), 1.
} 
short-term solutions while the fundamental problems caused by the existing laws 'ground on'. The group rejected this prospect, arguing that a change in the law in favour of sex workers would have a more substantive impact than the provision of welfare services within the existing framework. 'If the removal of imprisonment were brought about', McLeod argued, 'it would at a stroke remove the need for hundreds of mopping up operations to relieve the hardship that imprisonment brings' ${ }^{34}$

PROS was keen to situate its work in a historical frame of reference. For instance, one article in the group’s campaign Bulletin - which first appeared in the spring of 1977 and was published sporadically until 1982 - detailed the perceived links between the tactics used by PROS and the campaigns against prostitution laws that were spearheaded by Josephine Butler a century earlier. ${ }^{35}$ In terms of its organisational structure, however, the group's lineage was more properly in keeping the political activism that emerged out of the student protest movements of the late-1960s. This was evident in the suspicion PROS had of the funding system, as well as its embrace of a self-consciously non-hierarchical structure. In PROS, for instance, the chair and secretary were rotated at each meeting and efforts were also made to ensure that activities such as compiling the Bulletin were shared equally between its members. Mirroring the tactics commonly deployed by women's groups in the 1970s, the group also introduced a system for the provision of lifts to campaign meetings and, where appropriate, childcare facilities. ${ }^{36}$ The aim was to encourage a 'sense of investment' amongst existing members which would in turn allow PROS to expand out of its initial base in Balsall Heath. ${ }^{37}$ There were, however, difficulties in establishing a London-based branch of the movement. There, the scene in areas like King’s Cross was regarded by one activist as being

\footnotetext{
${ }^{34}$ McLeod, Women Working, 124.

${ }^{35}$ PROS Street Beat, no. 4 (1980), 6.

${ }^{36}$ McLeod, Women Working, 126-127. See also Sarah Browne, “'A veritable hotbed of feminism”: Women’s Liberation in St Andrew’s, Scotland, c. 1968-1979', Twentieth Century British History, 23 (2012), 103.

${ }^{37}$ McLeod, Women Working, 127.
} 
too fluid, with many women coming to London 'on day return tickets, work[ing] this area and return[ing] to their homes on the last train'. ${ }^{38}$ As Walkowitz has shown, this phenomena was so pronounced in the context of the rising unemployment of the early-1980s that these women were commonly referred to as 'Thatcher's girls' ${ }^{39}$ Although there was a degree of transiency in Balsall Heath, in smaller cities it was argued that there was a pre-existing sense of community and even 'solidarity' among sex workers that made the formation of local branches more straightforward. By 1979, PROS had emerged as a significant presence in Sheffield, Leamington, Coventry, Leicester and Bristol, and there were plans for the establishment of new branches in the port cities of Cardiff and Plymouth. ${ }^{40}$

\section{Coalition building}

From the beginning, PROS placed a significant emphasis on the importance of sex workers being at the core of the organisation. This was reflected in the group's constitution, which declared that only prostitutes could become members with voting rights, as well as its policy that 'working prostitutes [should] act as spokespeople for prostitutes'. ${ }^{41}$ While this was in keeping with the group's suspicion of 'hierarchies of knowledge' that prioritised academic over first-hand expertise, there was also a practical dimension: the involvement of women like Kim L and Nancy S was seen as a crucial means of recruiting more sex workers to the campaign. $^{42}$ Yet according to Garnett's depiction in Prostitute, this was not always a straightforward process. Towards the beginning of the film, the character played by Kim L is

\footnotetext{
${ }^{38}$ PROS Bulletin, no. 3 (1979), 5.

39 Judith R. Walkowitz, 'The politics of prostitution and sexual labour', History Workshop Journal, 82 (2016), 195; Walkowitz, 'Feminism and the politics of prostitution in King’s Cross in the 1980s', 236-238.

${ }^{40}$ Pros Bulletin, no. 2 (1979), 5-6; PROS campaign event, internal memo, c. October 1979, PROS papers, $1100 / 2 / 1$.

${ }^{41}$ PROS internal memo, c. 1979, PROS papers, 1100/1/1; Eileen McLeod, Women Working, 128.

${ }^{42}$ McLeod, Women Working, 128.
} 
seen attempting to recruit sex workers to PROS on the streets of Balsall Heath. The response, however, is uniformly negative. 'I just want to earn my money', one woman remarks. 'Do you mind moving on so I can earn my money?'43 Initially, Kim L reflected, 'the girls were frightened, more than anything else' because the idea of a campaign 'was all new to them' ${ }^{44}$ The reformist position of PROS was one tool the group used in an attempt to overcome this issue. Letters to potential members stressed that the group was attempting to remedy the concrete issues faced by street prostitutes in their day-to-day work, particularly the widespread use of fines and the prospect of imprisonment. ${ }^{45}$ Ultimately, however, it was the insider status of Kim L and others that proved to be the critical factor in the group's eventual ability to recruit new sex worker members. Letters to other women were commonly framed by phrases such as 'speaking from one pro to another', for example, and 'I am a girl like you' ${ }^{46}$ To the mind of Kim L, whatever the initial reluctance she encountered in Balsall Heath, in the end 'people trusted me because I was a girl'. As someone who was 'there all the time, people knew me', she concluded. 'Girls wouldn't have you in the house if they didn’t know they could trust you - they'd tell you to fuck off' ${ }^{47}$

The letter-pages of the PROS Bulletin reveal the extent to which the group's programme was increasingly gaining a sympathetic reception. In the 1979 issue, a divorced mother of two wrote to 'support... wholeheartedly' the PROS agenda. She regularly visited London 'to do a little hooking', the correspondent explained, but the 'narrow minded' attitude of her own small town meant that 'the people here would make my life (and that of my children) a misery' should her activities ever become public knowledge. The

\footnotetext{
${ }^{43}$ Quoted in Garnett, Prostitute.

${ }^{44}$ Interview with Kim L, 28 August 2018.

45 Quoted in McLeod, Women Working, 128.

${ }^{46}$ Nancy, letter to Jill, 19 March 1979, PROS papers, 1100/1/1; anonymous letter, quoted in McLeod, Women Working, 128.

${ }^{47}$ Interview with Kim L.
} 
correspondent nevertheless asked whether 'there is any way I can help (without putting myself in the shit)' ${ }^{48}$ The subsequent issue featured a letter from Mo, a call girl who worked indoors and had written to share her own fundraising tactic of asking each of her clients to contribute to a PROS donation box in the name of 'fair treatment and better laws'. ${ }^{49}$ In another letter, a self-styled member of the 'old school', who had been given a copy of an earlier issue by a probation worker, congratulated PROS on what she regarded as its 'intelligent precis of the game' and offered to encourage the participation of other women of her generation who 'may have some relevant info and ideas which may help your/our cause'. It was 'high time', she concluded, that 'all those twerps in high office realised we're not a lot of pexed-up slags, with no brains or morals'. ${ }^{50}$ For some sex workers, at least, the PROS campaign evidently came to provide a significant network of support. This was epitomised by another correspondent who wrote to PROS from prison, thanking the group for the 'first [letter] I've had since I came in here'. Although she explained that prison was 'really getting me down', she was excited by the prospect of eventually being able re-join the campaign. 'By the way I've got my own room back in Bristol', she wrote. 'Look forward to seeing you all soon, give my love to everyone and keep up the good work!!'51

This correspondence, whether printed in the pages of the PROS Bulletin or not, seemingly enabled sex workers to develop alliances that cut across differences of region and age, as well as between street prostitutes and those who worked in the off-street trade in brothels and massage parlours. On one level, this might be regarded as a process of 'consciousness-raising' in keeping with what had, by the late-1970s, become an established

\footnotetext{
48 J.D, quoted in PROS Bulletin, no. 2 (1979), 7.

${ }^{49}$ Mo, quoted in PROS Street Beat, no. 4 (1980), 9.

${ }^{50}$ MW, quoted in PROS Street Beat, no. 5 (c. 1981), 10.

${ }^{51}$ Sue, quoted in PROS Street Beat, no. 4 (1980), 9.
} 
feature of the women's movement. ${ }^{52}$ Certainly, the amount of space PROS devoted to the circumstances and everyday experiences of sex workers echoed the emphasis placed on the politics of the personal in both second-wave feminism and the burgeoning Gay Liberation Movement. ${ }^{53}$ The Bulletin also functioned as a source of practical information for prostitutes operating in different parts of the country. Each issue offered reminders about the legal status of prostitution and the way in which the system of fines and imprisonment operated, as well as details about sexual health matters, reports on the presence of dangerous clients, and updates on the particular tactics being deployed by vice squads in Birmingham, Manchester, Wolverhampton and elsewhere. ${ }^{54}$

Alongside this, however, the Bulletin also sought to reach outwards, beyond those who were directly involved with the sex industry. From 1980, for instance, the magazine (by now renamed Street Beat) included a new feature under the title of 'cookery corner'. This was ostensibly a straightforward means of members sharing recipes, but it was conceptualised politically - as a way of challenging the stereotype of the 'high-heel slut' and demonstrating to the general reader that 'we too run our homes and cook for our friends and families' ${ }^{55}$ There were also attempts to engage with the increasingly fraught politics of race in the period. ${ }^{56}$ PROS sought to align itself with a campaign that had emerged in the 1970 s to abolish the 1824 Vagrancy Act. Although this marked the first appearance of 'common prostitute' in law, in the 1970s it had become notorious because of the way in which it was being used by the police as the legal basis for its mass stop and search policies - particularly

\footnotetext{
52 See Browne, “'A veritable hotbed of feminism”, 114; Eve Setch, ‘The face of metropolitan feminism: the London Women’s Liberation Workshop, 1969-79’, Twentieth Century British History, 13 (2002), 179; Robinson et al, ‘Telling stories about post-war Britain’, 290.

${ }^{53}$ Mort, 'Victorian afterlives', 204.

${ }^{54}$ Anon., 'Street purge’, in PROS Street Beat, no. 4 (1980), 9.

55 Jayne Maynard, 'Smoke signal’, in PROS Street Beat, no. 4 (1980), 3.

${ }^{56}$ See Connell, Black Handsworth.
} 
in areas with large immigrant populations. ${ }^{57}$ A 1980 article in the PROS Bulletin, which was illustrated by a cartoon depicting an unsuspecting black woman about to be apprehended by a hidden police officer, sought to draw the connections between the criminalisation of primarily black and Asian youths and the ongoing treatment of sex workers - an increasing number of whom were themselves ethnic minorities. ${ }^{58}$ Under the terms of the 1824 Act, the police required little or no evidence of a crime having been committed in order to stop and search a suspect. PROS highlighted similarities between the discriminatory nature of this tactic and the powers given to the police by the 1959 Street Act to arrest 'common prostitutes’ without having to prove that a nuisance had been caused. ${ }^{59}$

PROS occupied a complex position within this milieu. At times it seemed more comfortable looking outwards than working with organisations which were also concerned specifically with the issue of sex work - particularly the ECP, whose radical platform and largely middle-class membership jarred with some members of PROS. In 1982, for example, the PROS Bulletin featured a cartoon depicting the ECP occupation of the Holy Cross Church. In the background, a group of protesters are shown on the steps of the church, chanting 'prostitutes of the world unite' in front of the glare of surrounding news-cameras. The foreground, however, depicts two sceptical onlookers, one of whom reflects: 'they wouldn't last five minutes in Bilston' ${ }^{60}$ If there was an anti-metropolitanism to PROS, the converse of this was a strong sense of provincial pride. This was further illustrated by the group’s 'stick around sticker' campaign, whereby supporters were encouraged to wear 'stop

\footnotetext{
${ }^{57}$ See Paul Lawrence, 'The Vagrancy Act (1824) and the persistence of pre-emptive policing in England since 1750’, British Journal of Criminology, 57 (2017), 513-31.

${ }^{58}$ Walkowitz, 'Feminism and the politics of prostitution in King’s Cross in the 1980s', 238.

${ }^{59}$ Anon., 'The other ““Sus”, in PROS Street Beat, no. 4 (1980), 6. See also Simon Peplow, ““A Tactical manoeuvre to apply pressure”: race and the role of public inquiries in the 1980 Bristol "Riot”, Twentieth Century British History, 29 (2018), 135.

60 The cartoon was by John Dalton, a community arts worker and supporter of PROS. See PROS Street Beat, no. 6 (c. 1982), 2.
} 
imprisonment' stickers and distribute them on street signs, walls and public doorways in Birmingham and elsewhere. The aim was both to recruit new members to the cause and provide a visualisation of what was seen as the growing momentum behind the campaign. ${ }^{61}$ As has been argued, stickers and other signage were commonly used by campaigners in this period as a means of garnering a sense of spatial identity. ${ }^{62}$ Such tactics were, moreover, likely to be more effective in cities outside London with less population fluidity and more navigable social and political networks. In autumn 1978, Helen Buckingham wrote to PROS requesting further information about this element of the campaign: 'the last time we met you were about to stick women-behind-bars stickers all over Birmingham' ${ }^{63}$ While this demonstrates the extent to which lines of communication were maintained with other campaigners, there was an understanding in PROS that it was necessary to reach out to wider audiences beyond the specific sphere of sex work activism. And given that, by the mid1970s, an extensive patchwork of feminist organisation had emerged across the country, it was perhaps inevitable that PROS increasingly focussed its energies on developing alliances with the women's movement in particular. ${ }^{64}$

Few of the key players in PROS arrived at the group well-versed in feminist analysis. Eileen McLeod described her own feminism as 'rather undirected', and was primarily motivated by what she saw as the disconnect between the stereotypical view of prostitutes and the 'independent' and 'well organised' women she regularly encountered as a probation officer in the 1970s. As Louise Webb reflected, PROS 'wasn't about going to Oxford University and everyone showing each other their vaginas' ${ }^{65}$ If Webb's hostility to the

\footnotetext{
${ }^{61}$ PROS Bulletin, no. 2 (1979), 3.

${ }^{62}$ See Chris Moores, 'Thatcher's troops? Neighbourhood Watch schemes and the search for 'ordinary'

Thatcherism in 1980s Britain', Contemporary British History, 31 (2017), 246.

63 Helen Buckingham, to PROS, 29 September 1978, PROS papers, 1100/1/1.

${ }^{64}$ Browne, “'A veritable hotbed of feminism”, 101.

${ }^{65}$ Interview with Louise Webb, 14 July 2018; McLeod, Women Working, 120-121.
} 
feminist agenda was tied up with her own working class formation, the detachment of Kim L stemmed from an enduring affinity to the conservative, gendered roles she encountered in childhood. 'I believe in women's rights', Kim L reflected, 'but at the same time, I was brought up in the old school. Our mum always had the dinner on the table, always cooked, always cleaned...that was always in me'. ${ }^{66}$

This distance from Women's Liberation, alongside the group’s reform-orientated programme, enabled PROS to sidestep longstanding controversies within the women's movement over the status of prostitution. In the 1970s these had re-emerged with fraught debates about who had the right to speak for sex workers, as well as the division between a libertarian tendency that sought to highlight the relative autonomy of sex workers in response to societal inequalities, and a radical strand that advocated prostitution's complete eradication as the extreme example of patriarchal exploitation. ${ }^{67}$ While many feminists gravitated towards this latter position in the context of the growing notoriety of the so-called 'Yorkshire Ripper', the lorry driver who between 1975 and 1980 murdered and attacked scores of women (many of them sex workers) in Leeds and Bradford, PROS was faced with the practical problem of how to maintain its focus on the agency of sex workers while at the same time expand the group's coalition of support so that it included links with the broader feminist movement. While in 1977 the first issue of the PROS Bulletin sold 500 copies, the group recognised that much greater media exposure was required if substantial feminist alliances were to be formed. ${ }^{68}$

\footnotetext{
${ }^{66}$ Interview with Kim L.

${ }^{67}$ Edwards, 'The legal regulation of prostitution', 68-69; Walkowitz, 'The politics of prostitution and sexual labour', 190; Juno Mac and Molly Smith, Revolting Prostitutes: the Fight for Sex Workers' rights (London, 2018), 9-18.

${ }^{68}$ PROS Bulletin, no. 2 (1978), 2; Anon., 'PROS and the media', PROS Bulletin no. 3 (1979), 9. On the 'Yorkshire Ripper', eventually revealed to be the Bradford-based Peter Sutcliffe, see Hilary Kinnell, Violence and Sex Work in Britain (Uffculme, 2007), 1-26; Louise Wattis, 'Revisiting the Yorkshire Ripper murders:
} 
In this respect, the appearance in March 1977 of an article on PROS in the feminist magazine Spare Rib proved to be an important catalyst. The aim was to demystify the nature of street prostitution through a focus on the testimony of the women involved: one prostitute recounted how she was charged with loitering offences upon leaving a PROS campaign meeting, while others reflected on the threat of violence from clients and the lack of concerted police action in response. Certainly, the platform of Spare Rib allowed for a focus on the legal status and working conditions of women rather than - as was often the case in publications aimed at a more general readership - a titillating emphasis on the cost and range of the sexual services provided. The author of a concurrent article on PROS in an 'alternative’ magazine, for example, framed his narrative around what was identified as the 'big, buxom...earth mother' features of one member, and the experience she had with one of her clients who 'wanted to be a cow' ${ }^{69}$ In Spare Rib, by contrast, members were afforded the space to contest both the sexism of such representations and what was identified as the enduring misconceptions around sex work in feminist circles. One woman refuted the liberal perception that prostitutes were 'pathetic, stupid victims' by emphasising her desire to be able to 'hustle in peace'. ${ }^{70}$ And in spite of the PROS policy that it should be active prostitutes who primarily advocated publicly on behalf of prostitutes, Eileen McLeod also featured prominently in the article. She accused sections of Women's Liberation of using 'the word “prostitute” in a really nasty way' when instead what PROS actually required was 'practical help': 'allies to lobby and to publicise our programme...centres to meet in and money to run the campaign'. ${ }^{71}$

\footnotetext{
interrogating gender violence, sex work, and justice', Feminist Criminology, 12 (2016), 1-20; Walkowitz, 'Feminism and the politics of prostitution in King's Cross in the 1980s', 240-241.

${ }^{69}$ Quoted in Anon, 'Pros and cons’, Birmingham Broadside (October 1977), n.p.

${ }^{70}$ Victoria Green, ““We’re not criminals”: prostitutes organise’, Spare Rib, 56 (March 1977), 17.

${ }^{71}$ Green, “'We’re not criminals”, 18.
} 
McLeod was no doubt aware of the reach of a magazine that, by the mid-1970s, had an average distribution of some 20,000 copies. $^{72}$ And in April 1978 McLeod authored her own article in the magazine, presenting the case for supporting PROS in terms that would resonate with what had become the central feminist concerns of single mothers and the gendered impact of rising unemployment. ${ }^{73}$ What this in some ways represented was an alternative form of 'consciousness raising' - one that targeted feminist activists rather than supposedly disadvantaged prostitutes. Certainly, these articles led to PROS being invited to speak at a growing number of women's groups - from those based at universities and polytechnics across the country to groups attached to local branches of the Labour Party. ${ }^{74}$ And the letters published in the group’s Bulletin are testament to a growing feminist interest in PROS. One correspondent, from a member of a 'women's socialist group' that had a particular interest in 'issues concerning ordinary working class women', wondered whether it would be possible for a PROS member to offer an insight into prostitution 'from your point of view...reasons for becoming a prostitute, how this affects your life, harassment from the law etc'. Another letter came from a recently formed feminist group at Portsmouth Polytechnic. 'We want to discuss prostitution', the correspondent explained, 'but feel very ignorant about it'. Would PROS consider coming to 'talk to us and join in a discussion??75

By the end of the 1970s, alongside its Bulletin and the articles in Spare Rib, PROS had featured in the Observer and on BBC West Midlands Radio, ATV, BBC 2 and BBC Midlands Tonight. This increased media exposure undoubtedly represented a coup for

\footnotetext{
${ }^{72}$ Selina Todd, 'Models and menstruation: Spare Rib magazine, feminism, femininity and pleasure', Studies in Social and Political Thought, 1 (1999), 61.

${ }^{73}$ McLeod, 'Prostitutes organise', 22-25.

${ }^{74}$ Anon., 'PROS diary', PROS Bulletin no. 2 (1979), 2l; Elaine Chrysosttomou, quoted in in PROS Bulletin, no. 2 (1979), 7; Anon., 'PROS diary', PROS Bulletin no. 3 (1979), 2.

${ }^{75}$ Chrysosttomou, quoted in in PROS Bulletin, no. 2 (1979), 7; J.R., quoted in in PROS Street Beat, no. 4 (1980), 10.
} 
PROS. But it evidently also placed some of its members in difficult situations. Following the 1977 Spare Rib article, for instance, in which a sex worker agreed that her council house could be used as a post box for PROS, the News of the World began door-stepping the woman’s home. ${ }^{76}$ In a separate incident following the appearance on Midlands Tonight, a member of PROS based in Leamington Spa was shown on television without her consent. In a subsequent letter to PROS she detailed the effect this had on her personal life. 'I was very surprised to see ME', she wrote. 'Very, very upset - annoyed - furious - and a whole lot of other things because no had told me about it'. The programme had led to her youngest son, 'from whom all this had been kept secret', finding out about her work as a prostitute. ${ }^{77}$ This was the risk that the PROS commitment to prostitutes advocating on their own behalf ran. The group's use of the media, and its ability to position itself as the 'authentic' voice of provincial prostitution in particular, was an important weapon in its attempt to develop mediatory alliances - with the feminist left and beyond. Yet PROS admitted that, to begin with, at least, they had often been 'taken in' by the media. ${ }^{78}$ It was perhaps regarded as a price worth paying towards its ultimate ambition of initiating legal change - one that could, as McLeod hoped, remedy many of the hardships faced by sex workers 'at a stroke'. ${ }^{79}$ By the start of the 1980s, aided by its increased media exposure, PROS could call on supporters far beyond the women's groups it had initially targeted. This included the Workers Education Association, the National Association of Probation Officers, and the increasingly radical National Council for Civil Liberties, to which PROS were formally affiliated in May $1978 .^{80}$ Within three years, Tony Garnett's Prostitute opened to the British public. Reviewers

\footnotetext{
${ }^{76}$ Anon., 'PROS and the media', PROS Bulletin no. 3 (1979), 9; McLeod, Women Working, 130.

${ }^{77}$ Brenda, to PROS Group Brum Division, 28 November 1979, PROS papers, 1100/1/1.

78 Anon., 'PROS and the media', PROS Bulletin no. 3 (1979), 9.

${ }^{79}$ McLeod, Women Working, 124.

${ }^{80}$ PROS Bulletin no. 2 (1979), 2. On the radicalism of the National Council for Civil Liberties in the 1970s, see Chris Moores, Civil Liberties and Human Rights in Twentieth Century Britain (Cambridge, 2017), 165-218.
} 
praised its ability to demonstrate the extent to which public 'hysteria' over 'sexual matters' was depriving 'ordinary, vulnerable women' of 'common justice'. ${ }^{81}$ While reactions did not match the public outcry over homelessness generated by Cathy Come Home, it nevertheless formed another element within a coalition of support that helped enable PROS to embark on a programme of political lobbying designed to bring about a change in the law.

\section{Lobbying}

The initial impetus for amending the legal landscape faced by prostitutes in the aftermath of the Wolfenden Report came in the context of the permissive legislation of the late-1960s. Between November 1967 and January 1970 there were three attempts to bring about legal change in the House of Lords, led by the left-wing Labour peer Lord Chorley. The aim was to remove 'common prostitute' from the statute books, though at each turn the wrecking tactics of political opponents meant that none achieved a second reading. ${ }^{82}$ The issue emerged again in 1974 when a Working Paper commissioned by the Home Office to look into the status of the legislation on 'Street Offences' called for modest reform, particularly in the areas of probation and 'kerb-crawling' ${ }^{83}$ The government's response, however, was to delay the matter once again, and in 1975 the question of the laws and penalties around sexual offences was referred to the Criminal Law Revision Committee for consideration. The minister responsible was Roy Jenkins, the Labour Home Secretary who had earlier been a key driver behind the signature social reforms of the 1960 s. $^{84}$

By the late-1970s, it was clear that there was growing momentum inside the Commons, influenced to a significant degree by the external pressure applied by the

\footnotetext{
${ }^{81}$ Nicholas Wapshott, 'Cassavetes's caustic view of life in the States', The Times, 13 February 1981, 11.

82 Self, Prostitution, 253.

${ }^{83}$ Self, Prostitution, 267; Vickers, 'Prostitution in the context of the Street Offences Act', 117.

${ }^{84}$ Self, Prostitution, 274.
} 
campaigns of PROS and the ECP. In March 1979 Maureen Colquhoun, the Labour MP for Northampton North, launched a private members' bill which sought to abolish the term ‘common prostitute' and amend both the 1956 Sexual Offences Act and the 1959 Street Act, which she regarded as an 'invitation to treat all prostitute women unjustly' and as an attack on their civil liberties and human rights. ${ }^{85}$ While the shape of the Protection of Prostitutes Bill was particularly informed by the lobbying of Selma James, who was a personal friend of Colquhoun's, developments in Colquhoun's private life - which provided a vivid demonstration of Britain’s enduring social conservatism a decade after its permissive moment - also played a part. Three years before she brought her Prostitutes Bill before the Commons, Colquhoun had been outed by the Daily Mail as gay, having left her husband for a female campaigner the previous year. ${ }^{86}$ Colquhoun became Britain’s first openly lesbian MP, and what she described as the 'terrifying prejudice' she subsequently encountered provided an additional motivation for the pursuit of a liberalising agenda. ${ }^{87}$ Colquhoun derided Britain's enduring 'sexual hypocrisies', and compared the oppression faced by gay women to the status of prostitutes, who she saw as being permitted to earn a living as 'sex objects' only so long as they are 'not working-class and victimised...by obsolete man-made laws' ${ }^{88}$ In Parliament, Colquhoun was unambiguous about her desire to 'jog the memory of the House about the bad legislation that was introduced in the post-Wolfenden era', and her ultimate ambition of abolishing all prostitution laws. ${ }^{89}$ Despite facing significant opposition from the Democratic Unionist Party’s Ian Paisley, who criticised Britain’s 'moral delinquency... in the wake of

\footnotetext{
85 Parliamentary Debates (Commons), 963, 6 March 1979, 1094.

${ }^{86}$ Matthew Parris and Kevin Maguire, Great Parliamentary Scandals: Five Centuries of Calumny, Smear and Innuendo (London, 2004), 237.

${ }^{87}$ Maureen Colquhoun, A Woman in the House (Brighton, 1980), 84. See also Sarah Crook, 'The Labour Party, feminism and Maureen Colquhoun’s scandals in 1970s Britain', Contemporary British History (2019 advanced access), 1-24.

${ }^{88}$ Colquhoun, A Woman in the House, 90-91.

${ }^{89}$ Parliamentary Debates (Commons), 963, 6 March 1979, 1094.
} 
what has been called "the permissive society"', the first reading of Colquhoun's Bill was passed with a 130-50 majority - though this was at least in part a reflection of a recognition that the Bill had little chance of becoming law as a result of the impending dissolution of parliament.

PROS played a supportive role in Colquhoun's campaign. In its aftermath, a representative wrote to congratulate Colquhoun on the 'moral victory' that the initial passing of her Bill represented, while in turn Colquhoun requested to become an associate member of PROS and emphasised that the movement as a whole 'must not fragment'. 90 The sense that 'the spirit of reform' remained 'very much alive' following the debate encouraged PROS to step up a letter-writing campaign to those who were deemed to be potentially sympathetic MPs, urging them to apply 'any additional pressure which you might feel able to bear', and positioning PROS as a potential source of further information about the legal status quo and the everyday experiences of those women who were primarily affected by it. ${ }^{91}$

In its attempts to lobby MPs, PROS made extensive use of the two key elements that characterised its organisational make-up: its ability to develop mediatory alliances that cut across a range of constituents, and its significant membership-base of sex workers who operated on the street, primarily in cities and large towns outside of London. In its letters to MPs, the group emphasised that the response it had garnered 'from University seminars to women's groups and local party political meetings' in Birmingham, Sheffield, Manchester and beyond - as well as its interventions across a range of media platforms - provided evidence of what it suggested was 'a distinct shift in public opinion in the twenty years since

\footnotetext{
${ }^{90}$ Malcolm Fowler to Maureen Colquhoun, 16 March 1979; Maureen Colquhoun to Malcolm Fowler, c. spring 1979, PROS papers, 1100/3/1.

${ }^{91}$ Malcolm Fowler to Tom Litterick, MP, 16 March 1979, PROS papers, 1100/3/1.
} 
the Street Offence Act was passed' ${ }^{92}$ Within this context, PROS situated the testimony of its sex worker members as a means of foregrounding the human effects of the existing laws around prostitution. Just as the membership of women like Kim L, Nancy S and others played a key part in enabling PROS to recruit other sex workers to its campaign, so the sense of authenticity that this bestowed also functioned as a critical element in its attempts to influence MPs and other politicians.

In April 1979, PROS was invited to give evidence to the House of Commons Expenditure Committee, which was chaired by the reform-minded Conservative MP Janet Fookes who, in the context of the growing publicity around the status of sex workers and parallel concerns about prison overcrowding, had taken an interest in the issue of women in the penal system. In contrast to the evidence heard by the Wolfenden Committee some twenty years earlier, the written material that PROS provided contained a detailed appendix made up entirely of case-studies written by women from across the country who had in various ways been affected by the legal status quo. This included Shirley, a 30-year-old from Leamington Spa who was seven months pregnant when she received a three month prison sentence for soliciting and who, upon her release, was evicted from her council house and therefore 'had to keep hustling'. It also included Linda, who at 26 had already been to prison three times in Sheffield and reflected that each time she 'still intended to come out and solicit again'. And it included Carol, a 26-year-old from Birmingham whose two-year-old son was taken into care when she was given a three month prison sentence for soliciting. 'It wasn't until I was inside that what had happened really hit me', she wrote. 'I missed [my son] terribly', and 'when I came out it took [him] a long time to settle'. Carol emphasised the 'hurt' she felt when her son 'talked a lot about the foster home', and her subsequent attempt

\footnotetext{
92 PROS, written evidence to Expenditure Committee (Education, Arts and Home Office Sub-Committee), H.C. Paper 61, xiv, session 1978-79, 2 April 1979, 285.
} 
to protect him by moving from street work to what she saw as the less dangerous massage parlour trade. $^{93}$

PROS made efforts to frame this testimony in ways that could tie in to growing political concerns about crime, the size of the prison population and the state of the national finances. ${ }^{94}$ The group suggested that the removal of imprisonment for the crimes of soliciting and loitering would amount to a 'considerable saving in public expenditure' - some $£ 3,000$ per individual, it estimated, once 'hidden' costs such as childcare were also taken into account. $^{95}$ But it was the first-hand views of women themselves that appeared to resonate most powerfully, something demonstrated by the verbal testimony PROS gave to the Expenditure Committee alongside both Selma James and Helen Buckingham in April 1979. Representing PROS was Kim L, who had by this point become one of the most publicly visible members of the group. What is striking about her appearance is the extent to which she was able to direct the discussion in such a way that it reflected the focussed nature of the PROS campaign as a whole. Unsurprisingly, given her much greater public profile, the early stages of the hearing were dominated by Buckingham, and centred on the question of her tax status (Buckingham was campaigning for Inland Revenue to formally recognise 'prostitute' as a self-employed occupation) and earning power (she suggested this was in the region of $£ 5,000$ per annum, a figure undoubtedly skewed by Buckingham’s own position at the wealthy end of the market). ${ }^{96}$ Kim L's intervention, by contrast, focussed specifically on the effects of the solicitation laws and their relationship to issues such as poverty, unemployment

\footnotetext{
${ }^{93}$ PROS, written evidence to Expenditure Committee (Education, Arts and Home Office Sub-Committee), 285286.

${ }^{94}$ Johanna Kantola and Judith Squires, 'Prostitution policies in Britain, 1982-2002', in Joyce Outshoorn (ed.), The Politics of Prostitution: Women's Movements, Democratic States and the Globalisation of Sex Commerce (Cambridge, 2004), 64-65.

${ }^{95}$ PROS, written evidence to Expenditure Committee (Education, Arts and Home Office Sub-Committee), 284.

${ }^{96}$ Helen Buckingham, quoted in Expenditure Committee (Education, Arts and Home Office Sub-Committee), 295.
} 
and family life. 'Most women cannot live on social security', she explained, before emphasising that, based on her own experience, 'it does not help to go to prison at all because when you come out of prison you are in more need of money than when you went in'. As with the 'cookery corner' feature of the PROS Bulletin, Kim L chose to appeal to her audience in ways that chimed with the centrality of motherhood to conservative understandings of femininity. It was crucial for the Committee to recognise that 'these girls...have got children', Locket explained. 'They only go to prison because they need things for the children'. ${ }^{97}$

By the early-1980s, even in the aftermath of the landslide election victory of a Conservative Party increasingly pushing a law and order agenda, it was clear that the momentum behind liberalising the existing prostitution laws had not abated. In April 1981 a new private members' bill was brought by Clive Soley, the newly-elected Labour MP for Hammersmith North. In his opening remarks to the Commons, Soley described the continued use of the term 'common prostitute' as 'the only example that I know of on the statute book in which a person is by implication said to be guilty before having pleaded' ${ }^{98}$ The Bill sought to bring an end to the use of this term, as well as to the practice of sentencing prostitutes to a period of imprisonment after their third or subsequent convictions. Soley's interest in reform arose from his previous occupation as a senior probation officer in London, though the influence of PROS was also apparent. ${ }^{99}$ As Soley introduced his Bill, he cited the example of Carol, whose case had earlier been brought to the attention of the Expenditure Committee by PROS and whose three month prison sentence had put pressure on her relationship with her infant son. 'The whole experience was a nightmare', Soley told the Commons. 'She had all the pressure of the extra financial strain, as well as the realisation of

\footnotetext{
${ }^{97}$ Kim L, quoted in in Expenditure Committee (Education, Arts and Home Office Sub-Committee), 296-298.

98 Parliamentary Debates (Commons), 6, 19 June 1981, 1318.

${ }^{99}$ Interview with Clive Soley, 4 July 2018.
} 
the devastating damage that the separation had done to her child. She came close to a nervous breakdown' ${ }^{100}$ Soley’s Bill passed without opposition, though the government asked that it be withdrawn, ostensibly pending the outcome of the Criminal Law Revision Committee's report on prostitution, which was due to publish its findings imminently. ${ }^{101}$ In the event, however, the government introduced its own legislation that pre-empted the findings of the Committee - perhaps as part of an effort to dilute the previous attempts made by Soley and Colquhoun. In October 1982, the Criminal Justice Act was hurried through Parliament. The term 'common prostitute' remained in place, along with the system of graduated fines for offenders. However, section 1 (2) of the 1959 Street Offences Act, which rendered imprisonment the ultimate penalty for convictions for 'loitering and soliciting for purposes of prostitution', was abolished. ${ }^{102}$

This was no more than a partial victory. Nevertheless, it was the achievement of PROS to contribute to the shaping of a consensus around the need for reform in a manner that placed the experiences of women like Kim L, Carol and others front and centre of the narrative, and which could draw on the support of a range of constituents from contrasting points on the political spectrum. As Clive Soley emphasised in the Commons debate around his 1981 Bill, those opposed to the imprisonment of sex workers now included the Prison Governors' Association, the National Association of Probation Officers, the British Association of Social Workers, the National Council for Civil Liberties, the Josephine Butler Society, the National Association for the Care and Resettlement of Offenders, and the Howard League. 'I have had not one letter from an organisation expressing hostility to the Bill', Soley claimed, and emphasised the importance of his Bill gaining support from both sides of the House - particularly in a political climate in which Labour politicians were

\footnotetext{
100 Parliamentary Debates (Commons), 6, 19 June 1981, 1321.

101 PROS Street Beat no. 5 (1982), 3.

102 Home Office, Criminal Justice Act (London, October 1982), 79.
} 
regularly dismissed as forming part of the 'loony' left. ${ }^{103}$ For Matthew Parris, the Conservative MP for West Derbyshire who had supported Soley's bid to bring about a change in the law, the 1982 Act was both 'sensible and modest'. It had become clear, he argued, that there was now 'a broad measure of support on both sides of the House and in the country for doing this' ${ }^{104}$

When in December 1982 the Criminal Law Revision Committee published its findings - which included a recommendation that kerb crawlers should also be made liable to prosecution - it acknowledged this sense of a shifting climate. ${ }^{105}$ 'During this century attitudes to and thinking about sexual morality and prostitution have changed', it argued, echoing the tone of Wolfenden twenty-five years earlier. 'Moralising [and] condemnatory language about sexual behaviour is generally disliked and certainly is disliked by members of the committee'. ${ }^{106}$ The afterlife of the permissive 1960s was, to the mind of Louise Webb, the full-time organiser at PROS, manifest as a palpable change in the culture. Saying "I am a prostitute”, Webb suggested, 'is not so horrific as it once was'. ${ }^{107}$ This was certainly overly optimistic. That it took a further 27 years for the term 'common prostitute' to be removed from the statute books is testament to the deep-rooted persistence of social stigma around prostitution. ${ }^{108}$ But the 1982 change in the law did constitute a victory of sorts. And it was one in which the resolutely mediatory tactics deployed by PROS, and spearheaded by women who had direct experience of the everyday effects of the legal status of street prostitution, performed a critical role.

\footnotetext{
${ }^{103}$ Parliamentary Debates (Commons), 6, 19 June 1981, 1320; interview with Clive Soley.

104 Parliamentary Debates (Commons), 16, 20 January 1982, 352.

${ }^{105}$ Frances Gibb, 'Kerb Crawling Law Proposed’, The Times, 10 December 1982, 2.

${ }^{106}$ Quoted in Self, Prostitution, 274.

${ }^{107}$ Quoted in McLeod, Women Working, 139.

${ }^{108}$ Home Office, Policing and Crime Act (London, November 2009), 18.
} 


\section{Conclusion}

It did not take long for the limitations of the 1982 Criminal Justice Act to become apparent. In its aftermath, the number of prosecutions for prostitution offences actually rose significantly, from 4,324 in 1982 to 10,674 two years later. With an eye on events in parliament, police forces across the country had embraced a 'get tough' approach to prostitution, designed to circumvent the liberalising effects of the change in the law. ${ }^{109}$ In spite of the Act's abolition of custodial penalties, moreover, prison remained a realistic prospect for sex workers thanks largely to the continued use of a system of fines. Across Britain the level of fines increased after 1982 and led to rising numbers of women facing prison as a result of non-payments. In 1981, the proportion of 'common prostitutes' who were imprisoned for defaults on fines represented two per cent of the total female prison population; within three years, that figure had risen to more than eight per cent. ${ }^{110}$ With key members of the group fatigued, ongoing financial difficulties and a sense of disillusionment among sex workers coming to terms with the renewed hostility of the legal system, the decision was taken to disband PROS.

There were by this point signs of growing tensions in the ongoing campaign for legal reform. In 1983, following the ECP’s occupation of the Holy Cross church, its co-founder Selma James criticised PROS for what she saw as its lukewarm support during the demonstration. 'If you're not with the people at [a time like] that', she argued, 'then you're not with the people'. The problematic nature of the 1982 legislation, and parallel debates about how best to approach the issue of male kerb crawlers, had perhaps led to a

\footnotetext{
${ }^{109}$ Susan M. Edwards, 'Prostitutes: victims of law, social policy and organised crime', in Pat Carlen and Anne Worrall (eds), Gender, Crime and Justice (Milton Keynes \& Philadelphia, 1987), 43.

${ }^{110}$ Edwards, 'Prostitutes', 46.
} 
magnification of the differences between the two groups. ${ }^{111}$ Yet for all that the 1982 Act was undoubtedly a disappointment for campaigners, it is important not to lose sight of the processes by which organisations sought to bring about political change. ${ }^{112}$ Alongside the ECP and the prominent role of Helen Buckingham in particular, PROS helped to make the experiences of prostitutes the subject of sustained political discussion. The focus the group kept to a single issue - the legal status of street solicitation, as opposed to the more overtly ideological interventions made by the ECP - facilitated the development of a campaign that took in feminists groups, solicitors, probation workers and other professionals, as well as reform-minded MPs, civil rights organisations and, crucially, practising sex workers. The ability of PROS to tread this mediatory path suggests another way of engaging with the wellworn narrative that positions the increasing centrality of 1970s identity politics as leading to the indelible fragmentation of the left. With its articles in Spare Rib and elsewhere, PROS undoubtedly challenged feminists to support the plight of sex workers in more practical ways. Yet at the same time, PROS took inspiration from the feminist approach to organisational structure and its emphasis on the political power of personal testimony. The commitment within PROS to prostitutes advocating on their own behalf could be problematic, not least when it led to sex workers being inadvertently exposed to family members. But it was the personalised element of the group's campaign that often resonated most effectively, particularly with parliamentarians such as Soley, who drew on the experiences of PROS members in an attempt to win support for his 1981 bid to implement a change in the law.

\footnotetext{
${ }^{111}$ Interview with Selma James, the Leveller no. 91 (Feb 1983), p. 16. On the issue of kerb crawlers in the 1980s, see Roger Matthews, Kerb-Crawling, Prostitution, and Multi-Agency Policing (London, 1993); Maggie O’Neill et al, 'Living with the other: street sex work, contingent communities and degrees of tolerance', Crime, Media, Culture, 4 (2008), 73-93; Walkowitz, 'Feminism and the politics of prostitution in King’s Cross in the 1980s', 233.

112 McKay and Hilton, Introduction, 10.
} 
The difficulty PROS had in developing a branch of the movement in the capital perhaps made it more inclined to take whatever exposure it could get from a Londonorientated media. Yet the group's strength in the smaller, comparatively stable, and apparently more community-orientated red-light districts of Birmingham, Sheffield and elsewhere was an important factor in its ability to recruit sex workers like Kim L and Nancy S. On the face of it, these women had little connection to the moves to implement the 'permissive' legislation of the 1960s, and the subsequent rise of the politics of gender, race and sexuality. As they themselves made clear, they were victims both of deep-rooted taboos around prostitution and the operation of a legal framework that made it virtually impossible to work without the prospect of imprisonment. Yet in sharing their experiences - whether in parliament, on film, or in the pages of Spare Rib and the PROS Bulletin - they provided a reminder that the liberalising ethos associated with the 1960s had never extended to women like themselves. However flawed it ultimately turned out to be, the 1982 Criminal Justice Act was the outcome of a growing consensus - shaped in no small part by PROS - that this situation needed to be addressed. As Margaret Thatcher sought to cement her electoral dominance, the case of PROS reaffirms the continual space for alternative political currents, and the 'complex interrelations...movements and tendencies' of a critical conjuncture. ${ }^{113}$

WORD COUNT: 11,562

${ }^{113}$ Williams, Marxism and Literature, 121. 